\title{
STRATEGI KEPALA MADRASAH DALAM MENINGKATKAN KOMPETENSI SOSIAL GURU DI MTS AL KHOIRIYAH 2 MULYOREJO DALEGAN PANCENG GRESIK
}

\author{
Siska Zahrotul Hidayah'), Muhammad Haris ${ }^{2)}$, Muh. Hasyim Rosyidi ${ }^{3)}$ \\ ${ }^{1}$ Institut Pesantren Sunan Drajat Lamongan, Indonesia \\ 2 Institut Pesantren Sunan Drajat Lamongan, Indonesia \\ 3 Institut Pesantren Sunan Drajat Lamongan, Indonesia \\ Email: siskazahrotulhidayah76@gmail.com¹, muhammadharis@insud.ac.id², hasyimrosyidi@insud.ac.id³
}

Dikirim: 15 November 2021 Direvisi: 20 desember 2021 Diterbitkan: 31 Januari 2022

\begin{abstract}
Abstrak: Strategi kepala madrasah dalam meningkatkan kompetensi sosial guru namun masih banyak guru yang kurang maksimal dalam berkomunikasi dengan baik. Kompetensi sosial ini juga berpengaruh terhadap pembentukan karakter siswa dan berpengaruh terhadap hubungan dengan masyarakat. Penelitian ini bertujuan menjawab beberapa rumusan masalah: 1) Bagaimana strategi kepala madrasah dalam meningkatkan kompetensi sosial guru?. 2) Apa saja faktor yang mempengaruhi dalam meningkatkan kompetensi sosial guru? Jenis penelitian ini termasuk penelitian kualitatif, yang menghasilkan data dan dianalisis dengan menggunakan metode diskriptif yang disesuaikan MTs. Al Khoiriyah 2 Mulyorejo. Data yang dihimpun menggunakan teknik wawancara,observasi, dan dokumentasi. Hasil dari penelitian ini, bahwa strategi kepala madrasah dalam meningkatkan kompetensi sosial guru Mts. Al Khoiriyah 2 Mulyorejo merupakan strategi collaborativ. Dan dalam meningkatkan kompetensi sosial guru, maka kepala madrasah mengikutsertakan guru dalam MGMP, Workshop, dan Pembinaan IT. Tidak hanya itu saja dalam setiap bulan sekali kepala madrasah mengadakan Rapat dan evaluasi serta mengikutsertakan guru dalam kegiatan masyarakat yakni Istighosah. Dengan begitu guru bisa menambah wawasan dan menjalin silaturrohmi dengan baik, sehingga meningkatkan hubungan interaksi dengan maksimal. Sesuai dengan strategi kepala madrasah tersebut memunculkan beberapa faktor ang mempengaruhi kompetensi sosial guru. Adapun faktor-faktor yang mempengaruhi dalam meningkatkan kompetensi sosial guru adalah adanya faktor latar belakang pendidikan setiap guru, Usia guru, pengalaman dalam pembelajaran, pengaruh dari dalam diri dan keadaan lingkungan. Adapun dari hasil penelitian tersebut disarankan untuk kedepanya kepala madrasah lebih memperhatikan permasalahan yang ada dalam lingkup lembaga madrasah, terutama dalam hal berkomunikasi yang baik. Sehingga guru, staff, dan siswa mampu menerapkannya dalam sehari-hari dengan maksimal. Dan perlu adanya forum yang menjembatani antara guru yang mengikuti pelatihan-pelatihan dengan maksut agar dapat menularkan ilmu yang telah didapatkan kepada guru yang lain. Sehingga dapat mengimplementasikannya..
\end{abstract}

Kata Kunci : : Strategi Kepala Madrasab; Kompetensi Sosial Guru. 


\begin{abstract}
The strategy of the head of madrasa in improving the social competence of teachers but there are still many teachers who are less than optimal in communicating well. This social competence also affects the formation of student character and affects relations with the community. This study aims to answer several problem formulations: 1) What is the strategy of the head of madrasa in improving the social competence of teachers?. 2) What are the influencing factors in improving the social competence of teachers? 'This type of research includes qualitative research, which generates data and is analyzed using a descriptive method adapted to MTs. Al Khoiriyah 2 Mulyorejo. The data collected using interview, observation, and documentation techniques. The results of this study, that the strategy of the head of madrasa in improving the social competence of Mts teachers. Al Khoiriyah 2 Mulyorejo is a collaborative strategy. And in improving the social competence of teachers, the head of madrasah includes teachers in MGMP, Workshop, and IT Guidance. Not only that, once a month the head of the madrasah holds meetings and evaluations and involves teachers in community activities, namely Istighosah. That way the teacher can add insight and establish good friendship, thereby increasing interaction relations to the maximum. In accordance with the madrasa principal's strategy, several factors affect the teacher's social competence. The factors that influence in improving the social competence of teachers are the educational background of each teacher, the age of the teacher, experience in learning, influences from within and environmental conditions. As for the results of this study, it is recommended that in the future the madrasa head pays more attention to the problems that exist within the scope of the madrasa institution, especially in terms of good communication. So that teachers, staff, and students are able to apply it in everyday life to the fullest. And there needs to be a forum that bridges between teachers who take part in trainings with the intention of transmitting the knowledge that has been obtained to other teachers. So you can implement.
\end{abstract}

Keywords : Strategy of the Head of Madrasab; Teacher Social Competence

\title{
Pendahuluan
}

Kemampuan guru dalam mendidik tidak hanya mampu mengembangkan ilmu pengetahuannya namun harus mampu menerapakan dan menyampaikan bagaimana ia mengajarkan ilmunya sehingga dapat dipergunakan atau dipraktekkan oleh siswa. Kompetensi sosial merupakan salah satu kompetensi yang harus dimiliki oleh guru. Dalam hal ini guru memiliki posisi yang strategis dalam pembelajaran dimana bersentuhan langsung dengan siswa. Kepala sekolah merupakan motor penggerak, penetu arah kebijakan sekolah yang akan menentukan bagaimana tujuan-tujuan sekolah dan pendidikan pada umumnya direalisasikan sehubungan dengan MBS (Manajemen Berbasis Sekolah), kepala sekolah dituntut untuk senantiasa meningkatkan efektifitass kinerja. ${ }^{1}$

Kompetensi sosial guru merupakan kemampuan guru untuk memahami dirinya sebagai bagian yang tidak terpisahakan dari masyarakat dan mapu mengembangkan tugas sebagai anggota masyarakat dan warga negara. Lebih dalam lagi kemampuan sosial ini mencakup kemampuan untuk menyesuaikan diri kepada ketuntutan kerja dan lingkungan sekitar pada waktu membawakan tugasnya sebagai guru. Untuk itulah seorang guru dituntut tidak hanya pandai menguasai bidang ilmu yang di tempuhnya dan diajarkan kepada siswa di sekolah tetapi juga ilmu itu juga harus di terapkan dimasyarakat agar tercipta

\footnotetext{
${ }^{1}$ E. Mulyasa, Menjadi Guru Profesional (Bandung: PT. Remaja Rosdakarya, 2003), 126.
} 
masyarakat yang madani. ${ }^{2}$ Kompetensi sosial guru seperti yang telah dikemukakan oleh E. Mulyasa adalah meliputi "berkomunikasi dan bergaul secara efektif, hubungan sekolah dengan masyarakat, peran guru di masyarakat dan guru sebagai agen perubahan sosial".

Kompetensi sosial yang dimiliki oleh guru MTs. Al Khoiriyah 2 Mulyorejo ini sangat berpengaruh terhadap pembentukan karakter siswa. Karena sebagai guru yang memiliki kompetensi sosial harus mampu mengembangkan sikap positif kepada siswa. Sehingga akan timbul permasalahan apakah seorang guru yang telah memiliki kompetensi sosial yang baik sudah mampu mengembangkan dan membentuk karakter siswa menjadi baik atau belum mampu mengembangkan kompetensi sosial yang dimiliki sehingga belum mampu membentuk dan mengembangkan karakter siswa. Jikalau pun masih ada siswa yang berkarakter kurang baik apakah bisa dikatakan seorang guru belum mampu mengembangkan kompetensi sosialnya. Tidak hanya berpengaruh terhadap pembentukan karakter siswa tetapi berpengaruh terhadap hubungan interaksi terhadap sesama guru, staf-staf, dan masyarakat.

\section{Metode Penelitian}

Peneliti menggunakan metode deskriptif kualitatif. Yang secara tidak langsung melalui proses observasi, dan wawancara secara langsung dan hanya melibatkan Kepala sekolah, Guru, Tenaga kependidikan dan siswa MTs. Al Khoiriyah. Penelitian kualitatif sering disebut metode penelitian naturalistik karena penelitiannya dilakukan pada kondisi yang alamiah atau disebut juga dengan metode etnographi, karena pada awalnya metode ini lebih banyak digunakan untuk penelitian bidang antropologi budaya dan disebut juga dengan metode kualitatif karena data yang terkumpul dan analisisnya lebih bersifat kualitatif. Dan dalam penelitian ini, instrumennya adalah orang atau buman instrument,maka peneliti harus memiliki bekal teori dan wawasan yang luas sehingga mampu bertanya, menganalisis, memotret, dan mengkontruksi situasi sosial yang diteliti menjadi lebih jelas dan bermakna. ${ }^{3}$

\section{Lokasi Penelitian}

Peneliti mengambil latar penelitian dilembaga madrasah “ MTs. Al Khoiriyah 2 Mulyorejo ", Seperti yang sudah digambarkan peneliti dalam bab di atas, madrasah tersebut merupakan lembaga madrasah yang dikenal oleh masyarakat. Banyak hal yang belum dipenuhi oleh para tenaga pendidik dalam melaksanakan tugas nya. Salah satunya dalam hal berintraksi dan berkomuikasi dengan sesama tenaga pendidik, siswa, wali dan juga masyarakat.

\section{Data dan Sumber Data}

Secara umum sumber data penelitian kualitatif adalah tindakan dan perkataan manusia dalam suatu latar yang bersifat alamiah. ${ }^{4}$

\section{a. Data Primer}

Menurut Lofland data primer adalah pengambilan data dengan instrumen pengamatan, wawancara, catatan lapangan dan penggunaan dokumen. ${ }^{5}$ Sumber data primer merupakan data yang diperoleh langsung dengan teknik wawancara informan atau sumber langsung. Adapun dalam penelitian ini sumber data primer adalah warga sekolah yang meliputi: Kepala Madrasah, Waka Kurikulum, 2 Guru MTs. Al Khoiriyah 2 Mulyorejo untuk memberikan keterangan strategi apa yang akan

\footnotetext{
2 Sudarwan Denim, Inovasi Pendidikan: Dalam upaya meningkatkan profesionalisme tenaga kependidikan (Bandung: Pustaka Setia, 2002), 32.

${ }^{3}$ M. Djunaidi Ghony \& Fauzan Almanshur, Metode Penelitian Kualitatif (Jakarta: Ar-Ruzz Media, 2014), 29.

${ }^{4}$ Lexy, J. Moleong, Metodologi Penelitian Kualitatif Edisi Revisi (Bandung : PT Remaja Rosdakarya offset), cet.33, 2014, 4

${ }^{5}$ Margono, Metode Penelitian Pendidikan (Jakarta: Rineka Cipta, 2010), 155.

155 | MUDIR: Jurnal Manajemen Pendidikan
} 
digunakan dalam meningkatkan kompetensi sosial Guru.

\section{b. Data Sekunder}

Sumber data sekunder adalah data yang digunakan untuk mendukung data primer yaitu melalui studi kepustakaan, dokumentasi, buku, jurnal, majalah, koran dan arsip tertulis yang berhubungan dengan obyek yang akan diteliti pada penelitian ini. Sumber sekunder merupakan sumber yang tidak langsung memberikan data kepada pengumpul data, misalnya lewat orang lain atau dokumen.

\section{Tekhnik Pengumpulan Data}

\section{Observasi}

Observasi adalah teknik pengumpulan data melalui pengamatan. Dengan melakukan observasi peneliti dapat mengamati objek penelitian dengan lebih cermat dan detail, misalnya peneliti dapat dituangkan ke dalam bahasa verbal.

Wawancara

Wawancara merupakan pertemuan dua orang untuk bertukar informasi dan ide melalui tanya jawab, sehingga dapat dikonstribusikan makna dalam suatu topik tertentu. Wawancara yang sering disebut juga dengan interview atau kuesioner lisan adalah sebuah dialog yang dilakukan oleh pewawancara untuk memperoleh informasi dari orang yang mempunyai sumber informasi. ${ }^{6}$

\section{Dokumentasi}

Dokumentasi adalah pengumpulan data dari data-data yang telah didokumentasikan dalam berbagai bentuk. Dokumentasi dari asal katanya dokumen yang artinya barang-barang tertulis. Di dalam melaksanakan metode dokumentasi, peneliti menyelidiki benda-benda tertulis seperti buku-buku, majalah, dokumen, peraturan-peraturan, notulen rapat, catatan harian dan sebagainya.

\section{Teknik Analisis Data}

Analisis data adalah proses mencari dan menyusun secara sistematis data yang memperoleh dari hasil wawancara, catatan, dan bahan-bahan lainnya. Sehingga dapat mudah dipahami dan temuannya dapat diinformasikan kepada orang lain. Analisis data dilakukan dengan mengorganisaskan data, menjabarkan ke dalam unit-unit, melakukan sintesa, menyusun kedalam pola, memilih nama yang penting dan yang akan dipelajari, dan membuat kesimpulan yang dapat diceritakan kepada orang lain. ${ }^{8}$ Dalam analisis data, peneliti menggunakan model interactive model, yang unsur-unsurnya meliputi berbagai macam yaitu:

a. Data Collection / Pengumpulan Data

Pengumpulan data adalah sebuah proses untuk memperoleh data yang disebut dengan data mentah. Data mentah tersebut terdiri dari data primer yang belum dipilih. Data diperoleh dengan wawancara, observasi dan dokumentasi.

b. Reduksi Data

Mereduksi berarti merangkum, memilah hal-hal yang pokok, memfokuskan pada hal-hal yang penting, dicari tema dan polanya. Dengan demikian data yang telah direduksi akan memberikan gambaran yang jelas dan mempermudah peneliti untuk mengumpulkan data selanjutnya dan mencarinya bila diperlukan dalam mereduksi data, setiap peneliti akan mengarahkan pada tujuan yang hendak dicapai. Pada penelitian kualitatif tujuannya adalah temuan.

c. Display Data / Penyajian Data

\footnotetext{
${ }^{6}$ Suharsimi Arikunto, Prosedur Penelitian Satu Pendekatan Praktik (Jakarta: Rineka Cipta, 2013), 199.

${ }^{7}$ Sugiono,Metode Penelitian Kuantitatif Kualitatif dan R\&D (Bandung: Alfabeta, 2007), 226.

${ }^{8}$ Sugiono,Metode Penelitian Kuantitatif Kualitatif dan R\&D (Bandung: Alfabeta, 2007), 224.
} 
Penyajian data merupakan proses penyusunan informasi secara sistematis dalam rangka memperoleh kesimpulan sehingga temuan penelitian di dalam penelitian ini data yang didapat berupa kalimat. Kata-kata yang berhubungan dengan fokus penelitian. Dalam hal ini Miles dan Huberman mengatakan " yang paling sering digunakan untuk menyajikan data dalam penelitian kualitatif adalah teks yang bersifat naratif”.

d. Conclusion drawing/ Verification (Kesimpulan data)

Kesimpulan dalam penelitian kualitatif merupakan temuan baru yang sebelumnya belum pernah ada. Temuan ini dapat berupa diskriptif atau gambaran suatu objek yang sebelumnya masih remang-remang atau gelap sehingga setelah diteliti menjadi jelas. Jadi setiap makna yang muncul dari data harus diuji kebenarannya, kekokohannya dan kecocokannya yakni validalitasnya. Peneliti pada tahap ini mencoba menarik kesimpulan berdasarkan tema untuk menemukan makna dari kata yang dikumpulkan.

\section{Findings and Discussion}

penelitian mengenai Strategi kepala madrasah dalam meningkatkan kompetensi sosial guru. Maka, peneliti menyesuaikan dengan rumusan masalah dan tujuan penelitian, serta disesuaikan dengan teknik analisis data sehingga dapat diambil kesimpulan dari permasalah yang diteliti. Adapun diantaranya sebagai berikut:

1. Strategi Kepala Madrasah Dalam Meningkatkan Kompetensi Sosial Guru di MTs. Al Khoiriyah 2 Mulyorejo

Dalam meningkatkan kompetensi guru di MTs Al Khoiriyah 2 Mulyorejo kepala madrasah harus menggunakan strategi yang tepat dan baik. Dari hasil interview dengan kepala madrsah, waka kurikulum, guru bahasa inggris, guru agama di MTs. Al khoiriyah 2 Mulyorejo mengungkapkan strategi kepala madrasah yaitu dapat dilihat dari bagaimana cara kepala madrasah dalam mendengarkan keluhan guru, mengambil keputusan yang diambil secara bersama, serta tindakan yang dilakukam kepala madrasah untuk meningkatkan kompetensi sosial guru. Sehingga tidak terpungkiri peran kepala madrasah dalam memimpin dan mengambil keputusan demi memajukan kualitas seorang guru dan pengembangan lembaga pendidikan, yang salah satunya meningkatkan kompetensi sosial guru.

Sesuai dengan teori yang ada, kepala madrasah dalam mendegarkan keluhan-keluhan guru dalam meningkatkan kompetensi sosialnya, hal ini menunjukkan sejauh mana keterbukaan yang dibangun antara guru dengan kepala madrasah terbukti dengan baik. Kemudian dalam menjalankan strateginya kepala madrasah MTs.Al khoiriyah 2 Mulyorejo dalam meningkatkan kompetensi sosial guru. Kepala madrasah mengklarifikasi apa yang telah guru sampaikan yang menghambat dalam menalankan sebagai guru yang berkomunikatif dalam berinteraksi. Dan dengan mengadakan rapat yang membahas tentang solusi dan pendapat kepala madrasah dan menyelesaikan permasalahan guru. Dan kepala madrasah memutuskan untuk memberikan pelatihan workshop bagi guru guna menunjang kompetensi sosial guru.

Kemudian sesuai dengan teori, sebagai kepala madrasah juga wajib memberikan keputusan dalam musyawarah dengan dewan guru. Dalam berinteraksi dengan siswa, guru maupun kepala madrasah. Maka semua yang ada di lembaga madrasah wajib berbicara atau berinteraksi dengan baik dan juga mensepakati untuk disiplin. Hal ini kepala madrasah sudah memberikan contoh pada guru-guru, siswa. 
Dengan ini, kepala madrasah memberikan tampilan pada guru-guru untuk diamati dan ditirukan oleh guru dan siswa bahwa dalam hal berbicara harus sopan santun, harus berbahasa dengan baik dan juga harus didplin. Bagi kepala madrasah dengan memberikan contoh merupakan tindakan yang sangat baik dan jika hanya memberi peraturan saja tanpa tindakan maka tidak akan terwujud.

Oleh sebab itu, peneliti mengamati dari hasil berbagai langkah yang dijalankan strateginya oleh kepala madrasah MTs. Al Khoiriyah 2 Muyorejo. Strategi yang digunakan adalah strategi Collaborative yang berarti bahwa tanggung jawab seorang kepala madrasah dan guru harus seimbang dalam menjalankan tugasnya. Antara kepala madrasah dengan guru sama-sama memegang peran dan fungsi dan saling mempengarui satu sama lain.

Selain itu, kepala madrasah juga berpengaruh terhadap pertumbuhan dan perkembangan guru dan stafnya. Apabila kepala madrasah mempunyai pembinaan dan inovasi yang bagus untuk mengembangkan potensi guru dan staffnya maka akan berpengaruh terhadap kompetensi sosial guru.

Kepala madrasah memiliki peranan dan tanggung jawab dalam meningkatkan mutu pendidikan madrasah dengan mempengarruhi, mengajak dan mendorong guru, siswa dan staf untuk menjalankan sesui dengan tugasnya, hal ini sesuai dengan teori, bahwasannya peranan kepala madrasah dalam mengelola tugas adalah dengan mengukur kemampuannya dalam menciptakan "iklim mengajar", dengan mempengaruhi, mengajak dan mendorong guru, murid, dan staff lainnya untuk menjalankan tugas dengan sebaik-baiknya. Selain itu, kepala sekolah juga berperan sebagai motivator dalam tugas. Kepala madrasah harus mendorong kepada para guru untuk membiasakan pada budaya mutu. Budaya mutu itu diwujudkan dengan memberikan wewenang para guru dalam meningkatkan mutu belajar mengajar, pembuatan keputusan dan diberikan tanggungjawab yang lebihbesar dalam melaksanakan tugas-tugas sebagai guru.

Dari hasil data temuan yang dilakukan peneliti, maka ditemukan beberapa strategi kepala madrasah dalam meningkatkan kompetensi sosial guru di MTs. Al Khoiriyah 2 Mulyorejo yakni:

a. Mengikutsertakan guru dalam kegiatan MGMP

Kompetensi sosial mengharuskan guru memiliki kemampuan komunikasi sosial yang baik dengan guru, siswa, kepala madrasah, staf wali siswa dan masyarakat. Sesuai dengan teori dari Arikunto bahwa kompetensi sosial yang baik dengan sesama guru. ${ }^{9}$ Dengan hal tersebut diadakannya MGMP yaitu forum atau perkupulan guru-guru mata pelajaran untuk pembinaan sebagai sara pendukung guru dalam meningkatkan kemampuan berkomunikasi. Dengan adanya MGMP tersebut bertujuan untuk menambah pengalaman, wawasan dan dapat bertukar fikiran dalam mencari solusi dalam meningkatkan komunikasi yang baik dan benar. Selain itu kegiatan ini sebagai mempererat silaturohmi antara guru sehingga tercipta kekeluargaan.

b. Mengikutsertakan guru kegiatan Workshop

Kompetensi sosial adalah kemampuan guru dalam berkomunikasi dan berinteraksi secara efektif dengan lingkungan sekolah maupun diluar lingkungan sekolah. Sesuai dengan teori Buchari Alma bahwa guru harus memiliki kemampuan dalam berkomunikasi dan berinteraksi secara efektif dengan lingkungan sekolah maupun di luar lingkungan sekolah. Oleh karena itu

${ }_{9}^{9}$ Arikunto, Dasar-Dasar Evaluasi Pendidikan (Jakarta: PT. Bumi Aksara, 1993), 239. 
strategi kepala madrasah dalam mengikutsertakan guru untuk mengikuti workshop yang ada itu untuk meningkatkan komunikasi, interaksi dan membuka wawasan. ${ }^{10}$

c. Pelatihan guru dalam pemanfaatan IT

Dalam pemberdayaan kompetensi sosial guru juga dimaksudkan untuk memperbaiki kinerja madrsah melalui kinerja guru agar dapat mencapai tujuan secara efektif, efesien dan optimal. Sesuai dengan teori dari Mulyasa, pemberdayaan kompetensi sosial guru juga dimaksudkan untuk memperbaiki kinerja madrasah mellui kinerja guru.11 Dalam hal ini dengan mengikiutsertakan guru dalam kegiatan pelatihan pemanfaatan IT dengan ini diharapkan guru dapat mengaplikasikan teknologi dalam pembelajaran dalam kelas dan diluar agar tercapai tujuan yang telah dinginkan.

d. Mengadakan Rapat dan Motivasi

Rapat merupakan hal wajib dalam kegiatan di lembaga madrsah, sebagai ajang bermusyawarah untuk menyelesaikan masalah-masalah yang telah dihadapi setiap guru, staffnya. Dengan begitu kepala madrasah mampu memberikan solusi dan pendapat sehingga bisa disepakati bersama-sama. Dengan demikian pula, motivasi adalah kebutuhan pribadi yang mendorong keinginan individu untuk melakukan kegiatan guna mencapai tujuan. Dengan begitu, sma halnya yang dilakukan kepala madrasah yaitu dengan memotivasi kinerja guru yang sangat penting dalam rangka untuk menciptakan proses pembelajaran yang bermutu dan menciptakan komunikasi yang baik dan benar. Dan dengan adanya motivasi dari kepala madrasah akan menyebabkan terjadinya kepuasan kerja yang menjadi tanggung jawab mereka.

e. Mengikutsertakan guru dalam kegiatan bermasyarakat

Kompetensi sosial dalam proses belajar mengajar berkaitan erat dengan kemampuan guru dalam berkomunikasi dengan masyarakat disekitar madrasah dan masyarakat merupakan tempat guru tinggal sehingga peranan dan cara tersendiri sedikit banyak perbedaan yang bukan misi yang demban oleh guru adalah misi kemanusiaan. Guru harus memiliki kompetensi sosial. Sama halnya dengan teori Jamal ma'mur asmani bahwa keikutsertaan guru dan siswadalam bermasyarakat adalah upaya kepala madrasah yaitu dengan melakukan kegiatan istighosah setiap hari jum'at pon di masjid dan di madrasah sebagai bentuk rasa syukur. Kegiatan ini bertujuan untuk memupuk kompetensi sosial guru dan masyarakat agar tetap menjalin silaturohmi dengan baik.

\section{Faktor-faktor yang Mempengaruhi Kompetensi Sosial Guru}

Setiap lembaga pendidikan pasti memiliki kendala atau faktor-faktor yang mempengaruhi dalam pelaksanaan kegiatan. Sesuai dengan teori, adapun faktor-faktor yang mempengaruhi kompetensi sosial guru di MTs. Al Khoiriyah 2 Mulyorejo sebagai berikut:

a. Latar belakang pendidikan

Dengan adanya perbedaan latar belakang pendidikan akan mempengaruhi kegiatan guru dalam melaksanakan interaksi belajar mengajar. Dalam hal ini sesuai dengan data temuan, bahwa latar belakang pendidikan guru di MTs. Al Khoiriyah 2 ini kebanyakan sudah Strata 1 (S1) sehingga dalam proses belajar mengajar sudah lebih luas wawasannya yang akan

\footnotetext{
${ }^{10}$ Buchari Alma, Guru Profesional: Menguasai Metode dan Terampil Mengajar, (Bandung: Alfabeta,2008), 148.

${ }^{11}$ E.Mulyasa, Standar Kompetensi dan Sertifikasi Guru (Bandung: PT. Remaja Rosdakarya, 2008), 173.
} 
diaplikasikan pada siswa. Namun masih ada beberapa guru yang latar belakang pendidikannya hanya MA tetapi tidak menutupi bahwa dalam proses pembelajarannya masih monoton dan kurang makasimal.

b. Latar belakang usia

Berdasarkan hasil data temuan, latar belakang usia merupakan faktor yang bisa mempengaruhi dan juga pendukung dalam proses pengembangan lembaga madrasah. Dikarenakan bahwa usia guru di MTs. Al Khoiriyah 2 ini, kebanyakan sudah berusia sepuh. Oleh karena itu dalam meningkatkan kompetensi sosial kepala madrasah tidak khawatir dalam berkomunikasi. Karena guru tersebut mampu membimbing guru lainnya dalam berinteraksi dengan masyarakat dengan baik.

c. Pengalaman dalam pembelajaran

Dalam hal ini, pengalaman dalam pembelajaran dapat mempengaruhi kompetensi mengajar guru, sebab pengalaman secara teoritis yang diterima dijenjang pendidikan profesi, tidak selamanya menjamin keberhasilan guru dalam mengajar. Apabila tidak ditunjang dengan pengalaman interaksi langsung dengan lingkungan belajar atau interaksi langsung dengan siswa.

d. Pengaruh dari diri dan lingkungan

Sesuai dengan teori yang ada, bahwa pengaruh dari diri sendiri merupakan sama halnya kecerdasan emosional. Kecerdasan emosional adalah kemampuan untuk mendengarkan bisikan emosi dan menjadikannya sebagai sumber informasi yang penting untuk memahami diri sendiri dan orang lain demi mencapai sebuah tujuan. Dan lingkungan juga, sebagai acuan dalam mencari ide-ide positif, namun bisa menjadi aktor yang menghambat dalam proses perkembangan lembaga.

\section{Kesimpulan}

1. Strategi kepala madrasah dalam meningkatkan kompetensi sosial guru di MTs.Al Khoiriyah 2 Mulyorejo. Strategi yang digunakan adalah strategi collaborative. Strategi yang lebih cepat membuat perubahan dalam mencapai tujuannya. Dan dalam meningkatkan kompetensi sosial setiap guru, maka kepala madrasah MTs. Al Khoiriyah 2 memberikan strategi dengan mengikut sertakan guru dalam MGMP, Workshop, mengadakan kegiatan Rapat dan memotivasi, pelatihan IT, mengikutsertakan dalam kegiatan masyarakat. Dengan begitu, guru bisa menambah wawasan dan menjalin silaturohmi dengan baik. Sehingga bisa mencapai tujuan yang diinginkan.

2. Adapun faktor-faktor yang mempengaruhi dalam meningkatkan kompetensi sosial guru adalah:

a. Adanya faktor latar belakang pendidik,

b. Latar belakang usia guru

c. Pengalaman dalam pembelajaran

d. Pengaruh dari dalam diri dan lingkungan

Beberapa faktor tersebut berasal dari faktor internal dan eksternal yang bisa mempengaruhi dalam meningktakan kompetensi sosial guru, namun bis menjadi faktor pendukung dalam meningkatkan kompetensi sosial guru.

\section{Daftar Kepustakaan}

E. Mulyasa, Menjadi Guru Profesional. Bandung: PT. Remaja Rosdakarya, 2003. 
Sudarwan Denim, Inovasi Pendidikan: Dalam upaya meningkatkan profesionalisme tenaga kependidikan, Bandung: Pustaka Setia, 2002.

M. Djunaidi Ghony \& Fauzan Almanshur, Metode Penelitian Kualitatif. Jakarta: Ar-Ruzz Media.

Lexy, J. Moleong, Metodologi Penelitian Kualitatif Edisi Revisi. Bandung : PT Remaja Rosdakarya offset, cet.33, 2014.

Margono, Metode Penelitian Pendidikan. Jakarta: Rineka Cipta, 2010.

Suharsimi Arikunto, Prosedur Penelitian Satu Pendekatan Praktik. Jakarta: Rineka Cipta, 2013.

Sugiono,Metode Penelitian Kuantitatif Kualitatif dan R\&DD. Bandung : Alfabeta, 2007.

Arikunto, Dasar-Dasar Evaluasi Pendidikan. Jakarta: PT. Bumi Aksara, 1993.

Buchari Alma, Guru Profesional: Menguasai Metode dan Terampil Mengajar. Bandung: Alfabeta,2008.

E.Mulyasa, Standar Kompetensi dan Sertifikasi Guru, Bandung: PT. Remaja Rosdakarya, 2008. 